International Journal of Applied Linguistics \& English Literature

ISSN 2200-3592 (Print), ISSN 2200-3452 (Online)

Vol. 1 No. 1; May 2012

\title{
Politics of Food, the Culinary and Ethnicity in Ruth Ozeki' My Year of Meat: An Ecocritical Reading
}

\author{
Saeed Kalejahi \\ Department of English language and Literature, Tabriz Azad University \\ PO box 51575-5311, Tabriz, Iran \\ Tel: +989395815274 Email: kalejahi@gmail.com
}

Received: 06-05- 2012

Accepted: 28-05- 2012

Published: 31-05- 2012

doi:10.7575/ijalel.v.1n.1p.82

URL: http://dx.doi.org/10.7575/ijalel.v.1n.1p.82

\begin{abstract}
The Canadian-American-Japanese writer and filmmaker Ruth Ozeki' My year of Meat is built around one major nutritional source_-protein or meat or, more exactly, beef. Applying an ecocritical method, but at the same time trying to not fall into the trap of mere ideology, the present article explores the question of authenticity and representation of politics of food, culinary and ethnicity in the aforementioned novel. In the following essay I will argue that in her novels, Ruth Ozeki employs a three-step narrative strategy: invocation, subversion, and redefinition. The problem Ozeki addresses in this novel is that of disclosing the invisible reality behind the visible surface of that which poses as the real. In doing so she moves the problem of authenticity beyond the realm of ethnic and culinary culture. Rather than examining it as a form of ethnic "self-exoticization" or treating it merely as a fiction about cultural purity, she presents the authentic as an indispensable attribute of an ecologically viable culture and as a marker of representational sincerity in a globalized media economy.
\end{abstract}

Keywords: ethnicity, ethics, hybridity, the culinary, representation, authenticity, inauthenticity intranarrative, resignification

\section{Genealogy}

The author of My Year of Meat (1998) and All Over Creation (2003), Ruth L. Ozeki built each of her two novels around one major nutritional source_-protein and starch, or more tangibly, meat and potatoes. Plotting her stories along the culinary practices, economic systems, and social habits associated with these foods, and locating them in a transnational and multicultural context, Ozeki (who began her artistic career as a documentary filmmaker) emerged as a writer ${ }^{i}$ during a time when food and ethnicity were gaining currency on the international book and media markets as subjects that promised experiences of authenticity. Witness the publication of novels and culinary autobiographies such as Chitra Banerjee Divakaruni's Mistress of the Spices (1997), Ruth Reichl's Tender at the Bone (1998), Ntozake Shange's If I Can Cook, You Know God Can (1998), and David Wong Louie's The Barbarians Are Coming (2000); the resurgent interest in the writing of food journalist M.F.K. Fisher or "vibration" cook Vertamae Smart-Grosvenor; the popularity and international box office success of films such as Ang Lee's Eat Drink Man Woman (1994) and Sandra Nettelbeck's Bella Martha (2001). All of these texts are concerned with issues of self-identity and cultural authenticity - be it Chinese, Indian, Jewish, Southern Black American, Italian, or German - as they manifest themselves through figures of the culinary. A similar list could be provided for studies on the history of food and the cultures of eating and drinking. Books like Sidney Mintz' Tasting Food, Tasting Freedom (1996) come to mind here, or Mark Bradford McWilliams' yet unpublished but highly informative dissertation From Sustenance to Resonance: Food as Metaphorical Identity in the Nineteenth-Century American Novel (2002), two studies that, like Doris Witt's Black Hunger (1999) and Eric Schlosser's Fast Food Nation (2001), investigate the relationship between "food and the politics of U.S. identity" (Witt, 1999). Denise Gigante's Taste: A Literary History (2005) investigates the metaphoric links between "aesthetic taste and the more substantial phenomena of appetite" (3), a relationship that found its early roots in Milton, became of primary interest to philosophers and poets during the age of (English) Romanticism, and continues to be relevant for understanding some of the cultural mechanisms in modern consumer societies. This upsurge of artistic, literary, scholarly and popular interests in food issues can be read as one version of the phenomenon that Hal Foster described as "the return of the real," a phrase that refers to the grounding of artistic and theoretical discourses in the materiality of objects,

Page $\mid 82$ 
International Journal of Applied Linguistics \& English Literature

ISSN 2200-3592 (Print), ISSN 2200-3452 (Online)

Vol. 1 No. 1; May 2012

bodies, events, and social sites rather than in concepts of culture as simulacrum, text, or electronic media event.

This brings us back to Ruth Ozeki. For putting meat at the symbolic center of her first, and potatoes at the symbolic center of her second novel points at the significance of the real, material stuff of everyday life for the formation of individual and cultural identities. In an interview she gave after the publication of All Over Creation, Ozeki acknowledged her interest in "meat and potatoes, hamburgers and French fries" as "the staples of the American diet. We are," she said, "a nation of meat and potatoes. When you're writing a novel, you want to write about issues of identity - in this case, national identity" (Clyne 2003). The meat-and-potato metaphor utilized by Ozeki to describe national identity evokes questions about the pathos of authenticity inscribed in that figure. Take, for example, the description of the San Francisco-based band Red Meat ${ }^{\mathrm{ii}}$ as a group of musicians "play[ing] country music the old-fashioned meat-and-potatoes way" (Arnold 2001). Their songs, as another critic observed, "bear an uncanny resemblance to real country music," thereby drawing attention to the fact that what may sound like "pure unadulterated country of the Bakersfield honky tonk variety" (Joulie 2002) is a musical style adopted to produce and simultaneously subvert, through the application of humor and comic twists in the lyrics, the nostalgia for a past when life was still as simple as a country western song.

In the following essay I will argue that in her novels, Ruth Ozeki employs a narrative strategy akin to lyrical one deployed by Red Meat: invocation, subversion, and redefinition. For reasons of space, I will concentrate my analysis on My Year of Meat. The problem Ozeki addresses in this novel is that of disclosing the invisible reality behind the visible surface of that which poses as the real. In doing so she moves the problem

of authenticity beyond the realm of ethnic and culinary culture. Rather than examining it as a form of ethnic "self-exoticization" iii or treating it merely as a fiction about cultural purity, she presents the authentic as an indispensable attribute of an ecologically viable culture and as a marker of representational sincerity in a globalized media economy.

\section{Representations}

Responding to the question of why she writes so much about food, Ozeki claims that "food is our fundamental identity" (Clyne 2003). Further elaborating on that notion and taking American culture as her representative example, she discloses the interplay of the material and the discursive that shape the culinary fundament of contemporary notions of self:

When you trace the chain of production of something as simple as a potato, you start to realize that in every bite, every mouthful you chew and swallow, you are taking into your body a series of decisions that you really have no idea about. You think you' re simply eating a french fry, but in fact, that fry is the result of a series of decisions that have been made by the Food and Drug Administration and the Environmental Protection Agency, by corporations and scientists, by marketing agencies and PR

firms, and it's hugely complicated. So this idea that the political is the personal, and the personal is political becomes very real.

The key phrase that prevents Ozeki from lapsing into a new, culinary essentialism is "you are taking into your body a series of decisions." But equally significant is the fact that these "decisions" materialize as the things we eat, and as such they wear the mask of the natural. This is the conceptual and thematic focus of Ozeki's novels. Taking the ethnic and cultural complexity of the United States for granted and acknowledging the social, political, emotional, and familial conflicts that occur within a multicultural society, she examines the figure of a racially and culturally mixed American self as it is defined and redefined through its relationship to nature. And she does so through the lens of food imagery. ${ }^{\text {iv }}$ In her novels Ozeki counterbalances a potentially nostalgic approach to nature as the most authentic anchor of American nationality with a narrative structure that exposes the ethical and aesthetic implications of nature's reality as a dish. This strategy allows Ozeki to simultaneously question the authenticity of nature as a socially and culturally normative absolute and to acknowledge the absolute value of nature as a concept indispensable for an ecological critique of instrumental reason.

Ozeki employs meat and vegetables as tropes that simultaneously gesture towards the real and the symbolic, i.e., to the past and present nature of animal, plant, and human bodies, as well as to the existence of these bodies after their entry into the symbolic world of America as it unfolds in the literary and cultural history of the United States. As technologically enhanced beef, cows are no longer animals but the things Ozeki's characters eat (or refuse to eat), thus representing human culture's most immediate mode of incorporating nature. At the same time, beef and potatoes are meaningful emblems of America's cultural self-identification, Page $\mid 83$ 


\section{때장 \\ International Journal of Applied Linguistics \& English Literature \\ ISSN 2200-3592 (Print), ISSN 2200-3452 (Online)}

Vol. 1 No. 1; May 2012

referencing the historical narratives of the continent's European colonization, the mythology of the cowboy, the ideology of Manifest Destiny, and the stories of Irish and Polish immigration. Ironically though, the potato, while indigenous to the Americas, has never achieved the same symbolic currency as an authentic medium of U.S. culture as has beef, the signature ingredient of the fast-food nation's core staple. ${ }^{\mathrm{V}}$

The consumption of bovine meat also acquired a hardly noticed poetic value in the wake of Walt Whitman's salutation of the body as "a locus of democratic energies" (Erkkila 1989: 177). "How is it I extract strength from the beef I eat?" asked Whitman in Song of Myself, immediately continuing his existential inquiry: "What is a man anyhow? What am I? What are you?" (Whitman 1983: 37-38). The inquisitive poet puzzles over questions of identity. He does not know what constitutes his humanity, his sense of self. And even though he may not know how, he does know that the flesh of a slaughtered full-grown steer, bull, ox or cow invigorates his body. With a few strokes of the poet's pen, beef becomes the source of America's democratic vitality, a poetic legacy that Ruth Ozeki revisits in My Year of Meat, her 1998 debut novel.

The title of the novel refers to a year in the life of aspiring documentary film maker Jane Takagi-Little, the author's fictional alter ego as well as the novel's protagonist and primary narrator. Growing up in the 1960s and 70s as the daughter of a Japanese mother and the descendant of "weather-beaten Anglo-Saxon farmers" (147) on her father's side, Jane describes herself, in an allusion to Grant Wood's famous painting, as "An American Gothic gone wrong" (ibid.). Because Jane needs money, she accepts a job as coordinator and location scout for a nameless Japanese TV production company commissioned to create a commercial program for promoting American meats in the Asian market. Sponsored by BEEF-EX" , "a national lobby organization that represented American meats of all kinds-beef, pork, lamb, goat, horse-as well as livestock producers, packers, purveyors, exporters, grain promoters, pharmaceutical companies, and agribusiness groups" (9-10), the program, airing as a reality show called My American Wife!, is packaged as a look into the kitchens of ordinary American families. Jane's bosses at the TV production company translate BEEF-EX's ${ }^{6}$, mandate "to foster among Japanese housewives a proper understanding of the wholesomeness of U.S. meats" (10) into a prescriptive list of parameters for representing American cultural authenticity. In a series of memos faxed across the Pacific (the novel is set in 1991, the pre-email era) the "desirable things" (11) in an American wife are seen as her "attractiveness, wholesomeness, warm personality" (11), which are considered to be enhanced by an "attractive, docile husband" and "attractive, obedient children" (12). These couples are then expected to live an "attractive, wholesome lifestyle" in an "attractive, clean house" with "attractive friends and neighbors" (12). "Undesirable things" that should not appear in My American Wife! are "physical imperfections," "obesity," "squalor" and "second class peoples" (12). And most importantly, the meat of choice is beef: "(NOTE: Pork and other meats is second class meats, so please remember this easy motto: 'Pork is Possible, but Beef is Best!')" (12).

In addition to neutralizing its claim to representing authentic American culture, the excessive repetition of the demand for "attractiveness" points towards the burlesque as the narrative mode in which Ozeki exposes the racism, classism, sexism, and trophism (i.e., the privileging of one nutritional resource over all others) of the show. When the representational prescriptions meet with resistance from Jane Takagi-Little and some of the American members of the crew, the production company seeks to make amends, but in fact corroborates existing stereotypes:

NOTE ON AMERICAN HUSBANDS_Japanese market studies show that Japanese wives often feel neglected by their husbands and are susceptible to the qualities of kindness, generosity, and sweetness that they see as typical of American men. Accordingly, our wives should have clean, healthy-looking husbands who help with the cooking, washing up, housekeeping, and child care. The Agency running the BEEF-EX advertising campaign is looking to create a new truism: The wife who serves meat has a kinder, gentler mate. (12-13)

The "NOTE ON RACE \& CLASS" justifies racism and classism, insisting that "the average Japanese wife finds a middle-to-upper-middle-class white American woman with two to three children to be both sufficiently exotic and yet reassuringly familiar" (13). And finally, the "NOTE ON ALL-AMERICAN VALUES" maintains that in the globalized economy of the 1990s, in which Japan was emerging as a major technological player, things such as "a spanking-new refrigerator or automatic can opener" represent the values of a post-WWII "old-fashioned consumerism" and, therefore, need to be replaced with "contemporary wholesome values, represented not by gadgets for the wife's sole convenience but by good, nourishing food for her entire family. And that means meat" (13).

It is important to point out that these notes on gender, race, class, and national values are actually written by

Page 84 
International Journal of Applied Linguistics \& English Literature

ISSN 2200-3592 (Print), ISSN 2200-3452 (Online)

Vol. 1 No. 1; May 2012

Jane Takagi-Little in order to "convey" (12) the TV production company's views on representational politics to her American "Research Stuff" (12). Mimicking the tone of the original memos, Jane's texts push the originals to their surrealistic limits. In addition, they identify the narrator as a person whose "cynical reason" (Sloterdijk) helps her to simultaneously fulfill the requirements of her job and articulate her frustration about the fact that although she became "a documentarian partly in order to correct cultural misunderstanding" (88-89) she now actively participates in cultural deception. Initially, Jane submits to representing a racially, socially, and sexually homogenized America, but she uses every opportunity to ridicule the idea that American cultural authenticity rests on the notion of white American middle-class wholesomeness. One way for her to do so is to suggest the inclusion in the program of recipes such as the one for "BEEF FUDGE," made out of " 2 cups white sugar / 1 1/2 cup ground beef / 1 cup brown sugar / 3 tablespoons butter / $1 / 2$ cup white corn syrup / $2 \mathrm{oz}$. unsweetened chocolate / 1/2 cup milk / $1 \frac{2}{2}$ cup walnuts / 1 teaspoon vanilla" (183-84). Jane ends the fax in which she presents this recipe to her Japanese boss, Joichi “John” Ueno, by asking him “Doesn't this sound delicious?” and signing off "Sincerely, J.Takagi-

Little" (184).

This passage is an important key for unlocking some of the poetological and philosophical concerns of the novel. Here and in the immediate textual environment, Jane Takagi-Little, the autodiegetic narrator, exposes her increasing discomfort as the inhabitant of the Weberian "iron cage" of economic necessity, a location in which she is expected to relinquish the ethical imperative of representational sincerity as a documentarian for a negative ethics of marketability. ${ }^{\text {vii }}$ In order to preserve her sense of self amidst the insane obligations of her work life, Jane initially adopts a style of satirical exaggeration and mock sincerity reminiscent of postmodern strategies of psychological self preservation and cultural representation. Yet she eventually realizes that cynicism, while it may preserve her psychological integrity as an individual, a biracial American, and a coordinator-cum-director working for corporate TV, it does not solve the problem of advancing her skills and her professional goals as a documentarian. Venting her anger about the "BEEF-EX people" to her lover, she complains:

They don't want their meat to have a synergistic association with deformities. Like race. Or poverty. Or clubfeet. But at the same time, the Network is always complaining that the shows aren't 'authentic' enough. Well, I've been saying if only they'd let me direct, I'd show them some real Americans. (57)

Determined to replace the faux authenticity decreed by the American meat lobby and corroborated by the Japanese TV production company with images of another American reality, Jane begins to deconstruct the imagined wholesomeness of the white, beef-consuming, middle American family by shifting the series' focus to people whose lives do not neatly match the prescribed framework of physical attractiveness and social respectability. The America she shows is inhabited by black families; families with ten children, eight of whom are adopted and of ethnic and national backgrounds different from that of their parents; families with physically disabled children, who prefer lamb to beef, ("Lamb was Lovable" but "un-American," 140/164); interracial lesbian families who "like meat, like the taste of it, but [...] would just never eat it the way it's produced here in America" (177). What Dyann, one of the lesbian wives, is referring to is a meat production system that relies on the illegal use of a growth hormone called diethylstilbestrol (DES), and on dubious practices of fattening cattle on factory-like feedlots where recycled animal proteins are the future mad cow's common staple, and even manure becomes part of the diet, a feeding method that is cynically described by one of the novel's characters as the epitome of organic waste disposal. Dyann's remarks catch Jane's attention and prompt her to investigate the system of industrial meat production in the United States. Thus begins the narrator's gradual transformation from self-described "cultural pimp" to investigative documentarian. An entry in her diary records the self-conscious quality of this process:

Went to the library and found more books on the meat industry. The DES stuff was only the tip of the iceberg. Why didn't I pursue this? I call myself a documentarian, but I've learned almost nothing about the industry that's paid for the shows. Paid me for these shows. (202)

Once Jane's awareness is raised, the narrative moves out of the American kitchen, away from the family dining table, and into American feedlots, thus not only shifting its thematic attention from the scene of food preparation and consumption to the scene of food production, but also abandoning the classic locations of the ethnic food novel and the culinary autobiography. To the extent that the narrator becomes aware of her own

Page $\mid 85$ 
International Journal of Applied Linguistics \& English Literature

ISSN 2200-3592 (Print), ISSN 2200-3452 (Online)

Vol. 1 No. 1; May 2012

implication in the dubious and absolutely unsavory practices of industrial meat production, the novel develops a metanarrative concern for what Jane calls "the ethics of representing" (211). When her Japanese boss, Ueno, insists on focusing the show on beef, Jane notes in her diary:

Ueno wants beef, and beef he shall have. [...] So here we go. I will probe [the meat industry's] stinking heart and rub Ueno's nose in its offal. No more fudge. I'm thinking slaughterhouses for the next show. A meat-packin' mama in Chicago, perhaps? Or a feedlot family? (202)

In addition to their immediate function of signifying modes of meat preparation and meat production, the "fudge" and the "slaughterhouses" in Jane's verbal rant symbolize modes of literary and cultural representation - the culinary burlesque described earlier in this paper on the one hand, and, on the other hand, the poetic fusion of fact and fiction adopted by literary muckrakers like Upton Sinclair or Rachel Carson. As the narrator (and her author) feel the need to switch representational modes from satire to (fictionalized) documentary, they find themselves confronted with the task of reconfiguring and reauthorizing authenticity as an expression of veracity rather than a mode of deception. This is not an easy task, given that the concrete political work of exposing the ecological malpractice of the beef industry involves dealing with another ideologically discredited concept, namely the natural.

About half way through My Year of Meat, the author articulates what I read as the philosophical and political motivation behind the writing of My Year of Meat. The scene I am about to describe occurs in the context of Jane Takagi-Little's memories of life as a biracial teenager in the American heartland. When other girls in their early teens "were assembling ideal boyfriends from the body parts of teen movie idols and lead guitarists," Jane figured that she had "the chance to make a baby who could one day be

King of the World. An embodied United Nations" (149). Unlike her peers, who turn to popular magazines, Jane turns to the library where she stumbles across a chapter on "The Races of Men" in Alex Everett Frye's Grammar School Geography (1902). During one of her visits with her mother back home in Minnesota, Jane checks out the book again, reading in its introduction that "In this book, man is the central thought" (154). In a flash of post-feminist rebelliousness and for no apparent narrative reason, the narrator hastens to emphasize that unlike other women, who "might object" to "Frye's use of the generic 'man' for 'human'," she regards such intervention "an intraspecific quibble" (154). This being said, she continues:

The conflict that interests me isn't man versus woman; its man versus life. Man's REASON, his industries and commerce, versus the entire world. This, to me, is the dirty secret hidden between the fraying covers. (154)

The immediate narrative context for the Jane's musings and her return to Frye's "The Races of Man" is her inability to conceive, a circumstance that she self-ironically ascribes to her racial hybridity ("Like many hybrids, it seemed, I was destined to be nonreproductive," 152). However, the larger context in which Jane develops an interest in the conflict of "man versus life" is her growing suspicion that her infertility-her "mulish sterility" (153), as she refers to it in yet another rhetorical gesture of cynical self-distancing-may in fact be the effect of technological manipulation of her mother's body. As it turns out, in order to increase her own fertility, Takagi-Little's mother had been prescribed regular doses of DES, the same substance that is used to accelerate the growth of cows. As Julie Sze formulated in a 2006 American Quarterly article: "women and animals are

linked in DES, not accidentally or incidentally, but through an American technological and medical culture that saw the improvement of nature through technology and increased efficiency as central to the larger cultural project of improvement and progress" (Sze 2006: 803).

Sze describes her critical project in "Boundaries and Border Wars: DES, Technology, and Environmental Justice" as "an American studies analysis of DES" (792) whose aim is to complicate "hybridity, purity, and nature as cultural concepts in technological and environmental studies" (792).

Ozeki's novel is recruited in this project, not so much for its literary merits as a translation of publicly available information (about DES and health) into persuasive fiction, but for the pedagogical value contained in the information presented in the narrative text. According to Sze, My Year of Meat raises the issues of technology and environmental justice in a way "accessible" (799) to undergraduate readers. And she "focus[es] on this novel because it resurrects the DES story long buried from popular consciousness" (799). Accordingly, she identifies the "key cultural question" of the novel not as one addressing the ethics of meat eating, but rather as one that

Page $\mid 86$ 
International Journal of Applied Linguistics \& English Literature

ISSN 2200-3592 (Print), ISSN 2200-3452 (Online)

Vol. 1 No. 1; May 2012

asks "how has meat been made different technologically, what kinds of food and social systems have developed in the last fifty years that are significantly different in scale and scope from older systems of production and consumption, and what do race and gender have to do with these changes?" (805). While I find Sze's formulation of the novel's "key cultural question" sharp and thought-provoking, it leaves another, equally important key question unaddressed - and that is the question about the "ethics of representing" which, if we take the literariness of the literary text seriously, always involves questions of poetic (or literary) authenticity. It designates the quality of a text that is dependent on the writer's ability to find narrative forms and rhetorical figures which best depict what Susan Sontag called "the foul realities, realities of rapture" (2007: 151).

In the final section I will address this problem, taking my cue from a point in the narrative when Jane Takagi-Little resolves to uncover "the health hazards of meat production" (211), a decision that forces the author to have her protagonist rethink the concept of authenticity. On a thematic level, authenticity undergoes a resignification from a commercialized anthropological to an ecological value; on a poetological level, authenticity signifies a fusion of storytelling and documentation.

\section{Authenticity and in Authenticity}

Shooting footage for an episode of My American Wife! on the cattle feedlot of the Dunn family, which is located in Colorado, "one of the most beautiful states in the country" (245), Jane discovers that the total submission of the animal body to a regime of profitable production, its industrial translation, as it were, from living organism to edible thing, has effects on the human body that are "much too ... real" (343) to be shown on television. The mythical Wild West, home to a long tradition of American cattle breeding, is also inhabited by Rose Dunn, a five year-old girl who suffers from "precocious puberty" (270), caused by her exposure to DES on her father's feedlot. After Jane becomes aware of the girl's condition, she convinces Rose's mother that filming the girl and creating a documentary may not only provide Rose with the medical attention she needs but also enlighten the larger public about the effects of illegal feeding practices on humans.

Jane's documentation of the faceless, grotesque body of a pre-school girl with premature pubic hair becomes the pathologically authentic site through which the author articulates the conflict between "Man's REASON, his industry and commerce" and life. If Whitman implicates beef in the poetic production of democratic bodies, Ozeki's narrative does something similar, albeit with critical twist. The beef that is supposed to symbolize American wholesomeness to Japanese audiences turns out to be contaminated; and it produces bodies that exhibit the effects of an economic and medical rationalism that contradicts their original functions as modes of sustaining human existence. As the location of a reality that some deem "too real” for public display, Rose Dunn's body becomes the site of a new authenticity, one that articulates an otherwise unrecognized and perhaps even unrecognizable "National Crisis" (248). The novel suggests that this crisis has been brought on through an excess of instrumental and commercial reason. Paradoxically, it is the monstrous body of a child, a body whose contours were defined by an act of cultural intervention into natural processes, that comes to authenticate the natural- not, however, as the material manifestation of a culturally uncontaminated, 'innocent' ideal, but as a force which, in Elizabeth Grosz's words, "provokes and incites the cultural by generating problems, questions, events that must be addressed and negotiated, symbolized, or left unrepresented" (Grosz 2005: 51).

In order to further elaborate on this idea, let me take a rather unconventional step across disciplinary boundaries and venture into the field of forestry. Interestingly, "authenticity" is one of the four general criteria suggested by the World Wide Fund for Nature to measure forest quality. What sounds like material for a joke actually turns out to be a conceptually evocative set of strategies for approximating the natural and the authentic in a way that allows us, in our own fields of literary and cultural criticism, to simultaneously question the idealizations of such concepts as nature and authenticity.

In a 1996 article for Biodiversity Letters (a journal that appears under the imprint of Blackwell Publishing), Nigel Dudley, environmental consultant and senior forest advisor for WWF-Int, describes authenticity as follows:

Authenticity can only be 'absolute' within a forest that has never experienced human interference. In practice, wholly 'natural' forests no longer exist except for isolated fragments. A more realistic working definition of an authentic forest might be a forest in which all the expected ecosystem functions can operate over time. (Dudley 1996: 7)

In Dudley's definition the "natural" is replaced by the "authentic," but the authentic retains a significant quality of the natural-ecosystemic sustainability. Later in the article, authenticity in forests is characterized as an effect of

Page $\mid 87$ 


\section{एतA \\ International Journal of Applied Linguistics \& English Literature \\ ISSN 2200-3592 (Print), ISSN 2200-3452 (Online)}

Vol. 1 No. 1; May 2012

careful management. In order to achieve the effect of authenticity through management, "some idea of the original ecosystem is important" (7), yet it can never "exactly duplicate the natural ecological

process of a forest" (8). In other words, authenticity in a forest is the repetition of a natural forest with a difference, that difference being an ecologically informed mode of cultural intervention. One of the measures suggested by Dudley for creating authentic forests is the "application of management techniques which mimic natural ecological processes" (8). Now, against this background and bearing in mind that, by definition, an ecosystem is "an ecological community together with its environment, functioning as a unit," we arrive at a definition of authenticity as the effect of a cultural performance (management) that makes it possible for a community as well as its individual members to exist in space and over time.

In Ruth Ozeki's novel, the illegal and hazardous practices of beef production epitomize what I suggest calling an ecological inauthenticity - animal proteins are fed to herbivores; the application of growth hormones overrides the pace of biological time. In the narrative logic of the novel, the ecological inauthenticity of meat production in feedlots mirrors the cultural and social inauthenticity of meat representation in reality shows such as My American Wife!. Ozeki juxtaposes these discredited forms of the authentic with two alternatives. I have already mentioned the authenticity of the grotesque body. Its pathological realness, once it becomes the subject of documentary film-making and storytelling, carries the potential to create the passionate effects that are necessary to "alter [social and political] outcomes" (My Year of Meat 360). The motif of cultural pathology introduced by the trope of the grotesque body finds its intranarrative counterpart in a story about kudzu, one of Japan's most vigorous mountain plants. First introduced to the United States in 1876, planting kudzu was highly recommended as a method to reduce soil erosion in the American South between the mid 1930s and 1950s. Nicknamed "the vine that ate the South," kudzu is now officially recognized as a pest weed by the U.S. Department of Agriculture. During one of their visits to the South, Jane's Japanese camera man recognizes the plant and teaches one of the subjects of My American Wife!, the father of a large family and owner of a restaurant, how to utilize kudzu in his kitchen. While this may not entirely solve the actual ecosystemic problems caused by kudzu, the narrative suggests that its ecologically authentic management as a nutritional resource may at least inhibit some of the undesired side effects. After all, the botanical monster can be eaten, as Rose, the 'human monster,' can be medically treated once her condition is no longer covered up. The metaphoric fields around Rose and kudzu demonstrate that Ozeki's approach to nature as a dish prevents her text from a nostalgic idealization of nature as the location of purity vis-à-vis the contaminated space of culture. In other words, her call for ecological authenticity is not motivated by a culturally regressive desire for a better, more 'natural' past, but for developing what Hans Jonas described as the "imperative of responsibility" in view of "the critical vulnerability of nature to man's technological intervention" (1984: 6). My Year of Meat is a novel whose author presents authenticity as a concept which, although blemished by its service to ideologies of purity and cultural discourses of nostalgia, is still valid as a measure of ethical conduct and literary sincerity.

\section{References:}

Arnold, G. (2001, January 18). Musical protein. Metro: Silicon Valley’s Weekly Newspaper. Retrieved August 26, 2008, from http://www.metroactive.com/papers/metro/01.18.01/red-meat-0103.html.

Clyne, C. (2003). Creating novel life forms-literally: the sataya interview with Ruth Ozeki. Retrieved August 26, 2008, from http://www.ruthozeki.com/reviews/satya.html.

Dudley, N. (1996). Authenticity as a means of measuring forest quality. Biodiversity Letters, 3, 6-9.

Joulie, L. (2002). Red meat: Alameda County line. Take country back. (February): Retrieved August 26, 2008, from http://www.takecountryback.com/reviews/redmeat0202.htm.

Erkkila, B. (1989). Whitman the political poet. New York: Oxford University Press.

Gigante, D. (2005). Taste: a literary history. New Haven and London: Yale University Press.

Foster, H. (1996). The return of the real: the avant-garde at the end of the century. Cambridge, MA: MIT Press.

Grosz, E. (2005). Time travels: feminism, nature, power. Durham and London: Duke University Press.

Horowitz, R. (2006). Putting meat on the American table: taste, technology, transformation. Baltimore: The Johns Hopkins University Press.

Jonas, H. (1984). The imperative of responsibility: in search of an ethics for the technological age. Chicago: University of Chicago Press.

Page | 88 
International Journal of Applied Linguistics \& English Literature

ISSN 2200-3592 (Print), ISSN 2200-3452 (Online)

Vol. 1 No. 1; May 2012

Karem, J. (2004). The romance of authenticity: the cultural politics of regional and ethnic literature. Charlottesville: The University of Virginia Press.

Sontag, S. (2007). At the same time: essays and speeches. London and New York: Penguin Books.

Sze, J. (2006). Boundaries and border wars: DES, technology, and environmental justice. American Quarterly, 58(3), $791-814$

Taylor, C. (1991). The ethics of authenticity. Cambridge, MA and London, England: Harvard University Press.

Trilling, L. (1971). Sincerity and authenticity. Cambridge, MA: Harvard University Press.

Whitman, W. (1983). Leaves of grass. (The 1892 Edition). New York et al.: Bantam Books.

Witt, D. (1999). Black hunger: food and the politics of U.S. identity. New York and Oxford: Oxford University Press.

Notes:

${ }^{1}$ Her books have won Ozeki several awards. For My Year of Meat she received the Special Jury Prize of the World Cookbook Awards in Versailles as well as the Kiriyama Prize, an award established in 1996 by a nonprofit organization, Pacific Rim Voices, in order "to recognize outstanding books about the Pacific Rim and South Asia that encourage greater mutual understanding of and among the peoples and nations of this vast and culturally diverse region" (The Kiriyama Prize, http://www.kiriyamaprize.org/). For her second novel, All Over Creation, Ozeki received the 2004 American Book Award from the Before Columbus Foundation, a prize that acknowledges "the excellence and multicultural diversity of American writing" (The American Book Awards/Before Columbus Foundation, http://www.bookweb.org/btw/awards/The-American-Book-Awards---Before-Columbus-Foundation.html), and the WILLA Literary Award for Contemporary Fiction issued annually to celebrate "outstanding literature featuring women's stories set in the West" (http://www.womenwritingthewest.org/willaaward.html). As these prizes and awards indicate, Ozeki's work circulates not only on the transpacific and transatlantic literary markets; her novels are also recognized as texts that address international, national, and regional as well as gender and ethnic sensibilities.

2 Their music made it onto the soundtrack of Marc Forster's Monster's Ball (2001), the film for which Halle Berry received an Academy Award for Best Actress.

${ }^{3}$ In The Romance of Authenticity, Jeff Karem referred to regional, ethnic, and racial "selfexoticization" (3) as an ambiguous strategy of gaining literary visibility on a national (or even international) scale. Discussing the growing interest in regional literature at the turn of the nineteenth century, Karem observed: "Works that have eschewed local color, rejected self-exoticization, or otherwise violated expectations of what is accepted as 'authentic' have found censure or cold reception" (ibid.).

${ }^{4}$ As one of the three principal modes of negotiating and representing the nature-culture relationship, food references the materiality of nature as a consumable thing in much the same way that landscape epitomizes aesthetic conceptualizations of nature as sublime space, and technology manifests the scientific perception and appropriation of nature as process.

5 In Putting Meat on the American Table (2006), food historian Roger Horowitz observed: "Meat supply and forms of meat have changed dramatically over American history, but beef has held a remarkably constant place in the nation's symbolic food universe" (18).

${ }^{6}$ Whether intended or not, the name of this fictitious organization alludes to the global nature of the problems addressed in the novel. BeefEx is also the real name for the biannual meeting of the Australian Lot Feeders Association. See http://www.beefex.com.au/about.htm (August 25, 2008).

7 With Lionel Trilling, Takagi-Little's pursuit of representational sincerity can be described as an effort of communicating "without deceiving or misleading" (1971: 58). 